\title{
Bilah Berputar sebagai Media Pembelajaran Olah Tubuh untuk Melatih Gerak dalam Pengendalian Diri
}

\author{
Sarjiwo $^{1}$ \\ Program Studi Pendidikan Seni Pertunjukan, Fakultas Seni Pertunjukan, \\ Institut Seni Indonesia Yogyakarta
}

\begin{abstract}
The Rotating Blades as the Learning Media of Body Exercise to Train Movement in Self-Control. This study aims to reveal how media (blades) becomes the learning media of body exercises to train motion in self-control. This research is experimental research by giving treatment to research subjects. The treatment was carried out in three stages: (1) The study subjects adapted to the blades moving freely for 2 minutes; (2) the research subjects improvised motion freely while rotating the blades for 2 minutes; and (3) the research subjects improvised movement freely while turning the blades consciously to control themselves for 2 minutes. The motion process in the first, second, and third treatments was observed as the data for analysis. The observation was conducted by interviewing the research subjects. The results showed that in the first treatment, the blades that the research subjects rot hit the body, hit the floor, and slack ropes accumulated twelve times. In the second treatment, the research subjects rotated the blades hitting the body, hitting the floor, and the slack ropes were cumulatively 21 times. And in the third treatment, the blades were rotated by the research subjects hitting the body, hitting the floor, and the slack ropes accumulated seven times. The research results indicate that if the free movement is not controlled, the possibility of an accident is more significant (21 times). Meanwhile, if the movement is controlled, the case of an accident is more minor ( 7 times).
\end{abstract}

Keywords: rotating blade; body exercise; self-control

\section{Pendahuluan}

Kualitas kepenarian diperlukan untuk mendukung penampilan disebabkan bahwa pertunjukan tari bersifat sesaat. Oleh karena bersifat sesaat, maka seorang penari harus menunjukkan kemampuannya dalam menghayati dan mengekspresikan keinginan tari agar mempunyai daya pikat bagi penonton. Kemampuan menghayati tokoh peran akan menghasilkan seni yang berkualitas. Seni yang berkualitas pada umumnya merupakan hasil penghayatan yang dalam dari seorang seniman atas realitas kehidupan (Astuti dalam Zuchdi,
2011). Kualitas pertunjukan akan menjadi perantara bagi penonton dalam mengikuti proses pertunjukan untuk mendapatkan santapan batin. Oleh karena itu, seorang penari diharapkan melakukan latihan secara kontinyu sebelum karya tari dipentaskan. Selain itu, latihan tidak hanya dilakukan selama proses persiapan untuk pentas, tetapi diperlukan latihan secara teratur dan terusmenerus agar tubuh mampu beradaptasi dengan berbagai ragam gerak. Tanpa adanya latihan secara kontinyu, dapat mengakibatkan kondisi tubuh kurang terjaga kelenturannya. Tubuh penari harus dilatih dan dibentuk

\footnotetext{
Alamat korespondensi: Program Studi Pendidikan Seni Pertunjukan, Fakultas Seni Pertunjukan, Institut Seni Indonesia Yogyakarta, Jalan Parangtritis Km 6,5 Sewon Yogyakarta 55185. Email: sarjiwo@isi.ac.id; HP.: 081578887707.
} 
dengan cara olah tubuh, yakni kegiatan aktif melatih tubuh penari. Latihan dilakukan untuk menyiapkan dan membentuk raga penari serta mutu gerak penari (Setiyastuti, 2011). Selain itu, seringnya latihan dapat menjadikan tubuh semakin cerdas. Bagi seorang penari, kecerdasan tubuh diperlukan agar tubuh mampu melakukan berbagai ragam gerak secara artikulatif. Seorang penari diharapkan mempunyai kecerdasan tubuh yang dinamakan bodily kinesthetic.

Bodily-kinesthetic: Expertise in using one's whole body to express ideas and feelings (e.g., as an actor, a mime, an athlete, or a dancer) and facility in using one's hands to produce or transform things (e.g., as a craftsperson, sculptor, mechanic, or surgeon). This intelligence includes specific physical skills such as coordination, balance, dexterity, strength, flexibility, and speed, as well as proprioceptive, tactile, and haptic capacities (Armstrong, 2009).

Capaian kualitas kepenarian dapat diketahui pada saat penari menjadi bagian dalam pertunjukan tari. Pertunjukan sebagai hasil akhir suatu proses yang telah dilakukan dapat menunjukkan indikator capaian kualitas seorang penari. Seorang penari akan menunjukkan seluruh potensinya pada saat berpentas. Kemampuan dan kualitas penari akan teruji saat berpentas. Kekurangan ataupun kelebihan dapat terlihat pada saat pertunjukan berlangsung. Kelancaran dalam menyelesaikan seluruh koreografi tanpa adanya "kecelakaan" di luar dari kepentingan koreografi diperlukan latihan terus-menerus. Oleh karena itu, latihan olah tubuh diperlukan untuk mengeksplorasi kemampuan tubuh. Latihan olah tubuh di dalamnya termuat proses adaptasi kemampuan otot dengan subjek sebagai pengelola tubuh. Dirinyalah yang paling tahu tentang bagian tubuh mana yang bisa dan yang tidak bisa melakukan suatu gerakan. Pengetahuan tentang keadaan diri sebagai kendali dalam aktivitas gerak. Apabila proses latihan olah tubuh terjadi pemaksaan di luar kendali diri, maka dapat mengakibatkan cedera otot ataupun terjadi "kecelakaan" pada saat bergerak. Agar terhindar dari kondisi tersebut maka diperlukan proses latihan agar subjek mempunyai kesadaran pengendalian diri saat bergerak (menari).

Adanya peristiwa penari yang patah tulang pada telapak kaki, kaki terkilir, terpeleset, tubuh penari terkena properti tari, dan beberapa peristiwa lainnya, menunjukkan bahwa pada saat menari diperlukan kontrol atau pengendalian diri. Artinya, keterampilan teknik semestinya disertai dengan pengelolaan emosi, bukan semata-mata perihal teknik gerak. Setelah muncul berbagai pendidikan ketubuhan (secara mainstream sebut saja tari, teater, musik), nilai-nilai spiritual itu direduksi dalam laku keterampilan tubuh yang terbatas dan hanya sampai pada tataran teknik sematamata (Widaryanto, 2019). Oleh karena itu, menjadi sangat penting (urgent) diperlukan media pembelajaran yang dapat melatih kesadaran terhadap pentingnya bergerak yang dikaitkan dengan pengendalian diri. Dengan demikian, media bilah berputar diharapkan dapat diterapkan dalam pembelajaran olah tubuh yang dikaitkan dengan latihan pengendalian diri dalam bergerak.

\section{Pembahasan}

Pembuatan bilah yang terbuat dari kayu mahoni dilakukan oleh pengrajin kayu dan topeng bernama Bapak Sujiman dari Desa Bobung, Putat, Gunungkidul, Daerah Istimewa Yogyakarta. Desa Bobung merupakan sentra kerajinan kayu dan topeng yang dikenal sebagai salah satu desa wisata di daerah Gunungkidul. Kondisi pandemi Covid 19 berdampak terhadap kehidupan dan produksi para pengrajin di Desa Bobung. Demikian pula, kondisi pusat kerajinan kayu dan topeng Karya Manunggal yang dikelola oleh Bapak Sujiman, berhenti berproduksi. Karyawan yang berjumlah dua puluh lima orang beralih profesi sebagai tukang ataupun kuli bangunan. Oleh karena itu, pembuatan bilah dikerjakan 
sendiri oleh Bapak Sujiman. Kayu mahoni sebagai bahan dasar bilah diproses pada saat kayu masih dalam keadaan basah setelah ditebang. Hal tersebut dilakukan agar proses pembuatan bilah lebih lunak dan mudah dibentuk.

\section{Deskripsi tentang Bilah sebagai Pembelajaran Olah Tubuh}

Bilah sebagai media pembelajaran olah tubuh untuk berlatih gerak dalam pengendalian diri merupakan media hasil perancangan. Gagasan perancangan media pembelajaran untuk melatih olah tubuh dalam pengendalian diri muncul dari permainan kayu penggaris di masa sekolah dasar sekitar tahun 1970-an. Sewaktu duduk di Sekolah Dasar (SD), pada umumnya kayu penggaris di salah satu ujungnya dilubangi dan diberi tali sebagai alat bermain agar dapat bersuara. Memori masa kecil menjadi pemantik untuk memanfaatkan hasil suara menjadi dasar perancangan dalam pembuatan bilah. Bilah dirancang dan dimodifikasi sebagai media pembelajaran olah tubuh yang dikaitkan dengan kesadaran dalam pengendalian diri saat bergerak.

Penamaan bilah berputar didasari oleh cara penggunaan bilah dalam menghasilkan suara. Timbulnya suara disebabkan adanya tekanan kuat bilah pada saat berputar terhadap udara yang kompresibel. Pada saat bilah diputar akan mengeluarkan suara sebagai penanda banyak-sedikitnya tenaga yang dikeluarkan subjek. Bilah berbentuk pipih dengan panjang kurang lebih tiga puluh centimeter, lebar sembilan centimeter, dengan ketebalan bilah pada bagian tengah kurang lebih satu centimeter, dan semakin menipis ke sisi tepi dengan ketebalan kurang lebih 0,2 cm. Pada sisi salah satu ujung bilah dilubangi untuk diberi tali pengikat. Tali pengikat berbahan dari tali benang jaring sebagai penghubung antara bilah dan subjek. Pemakaian tali pengikat berbahan tali benang jaring dengan pertimbangan keuletan agar tidak mudah putus dan terlepas. Cepat-lambatnya putaran bilah tergantung dari kuat-lemahnya tenaga yang dikeluarkan oleh subjek dalam memutarkan benang jaring yang tersambung dengan bilah. Semakin kuat tenaga yang dikeluarkan subjek dalam memutarkan tali benang jaring, maka bilah akan berputar dengan cepat dan menghasilkan suara semakin nyaring. Sebaliknya, apabila subjek mengurangi tenaganya maka berputarnya bilah semakin lambat sehingga suara semakin melemah.

Keras-lemahnya suara bilah merupakan penanda terhadap kuat-lemahnya tenaga yang dikerahkan subjek dalam memutarkan bilah. Hasil suara bilah yang berputar inilah yang digunakan sebagai indikator terhadap pengelolaan tenaga subjek. Bagi seorang penari, pengelolaan tenaga diperlukan agar mampu menyelesaikan seluruh koreografi yang menjadi tanggungjawabnya. Tanpa adanya kesadaran dalam mengelola tenaga yang selaras dengan kebutuhan koreografi dan kapsitas tubuh, maka seorang penari akan cepat kelelahan. Tenaga yang berlebihan dan tidak selaras dengan kapasitas tubuh, dapat memunculkan gerak yang cenderung over acting. Penglebih-lebihan (over acting) yang dapat menjerumuskan pada perilaku gerak di luar koreografi. Selain itu, kemungkinan terjadi sesuatu yang tidak diharapkan dapat saja terjadi. Oleh karena itu, diperlukan proses pembiasaan dengan latihan olah tubuh yang disertai kesadaran dalam pengendalian diri. Latihan pengendalian diri diperlukan agar berbagai gerak yang dilakukan tetap dalam kesadaran dan kapasitas tubuh. Kemampuan mengendalikan emosi menjadi kunci menuju kestabilan emosi (Sabrina, 2020). Kestabilan emosi yang dapat memposisikan pada kesadaran terhadap kemampuan tubuh dalam melakukan gerak-gerak yang dibingkai koreografi agar tidak terjadi over acting.

Sebagaimana telah dipaparkan pada bagian sebelumnya bahwa berputarnya bilah tidak lepas dari tali pengikat bilah. Tali bilah merupakan penghubung antara subjek dan bilah. Keberadaan tali bilah tidak lepas dari fungsi tali sebagai pengantar tenaga dari 
subjek. Pada saat ujung tali bilah dimainkan subjek agar bilah berputar, maka tali bilah akan meregang selaras dengan tenaga yang dikeluarkan subjek. Semakin kuat dalam memutarkan bilah, maka tali bilah akan semakin meregang. Selanjutnya, bilah akan berputar cepat dan menghasilkan suara nyaring seperti suara segerombolan tawon terbang. Sebaliknya, apabila tenaga semakin lemah maka tali bilah akan mengendor yang mengakibatkan bilah terjuntai ke bawah. Kendor dan meregangnya tali bilah ini dapat diadopsi dalam pembelajaran tentang konsep kendho kenceng dalam tari. Bagi seorang penari, pengelolaan tentang kuat-lemahnya (kendho kenceng) tenaga diperlukan agar mampu memunculkan dinamika gerak. Tentu saja proses gerak dalam tari-tari tidak selalu dilakukan dengan pengerahan tenaga secara terus-menerus, tetapi diperlukan pengendoran tenaga. Pengendoran yang masih dalam sikap dan perilaku ebahing saranduning badan (bergeraknya seluruh bagian tubuh).

\section{Proses Perlakuan (Treatment) Latihan Olah Tubuh dengan Bilah}

Subjek yang dikenai perlakuan (treatment) adalah para mahasiswa dari Program Studi Tari dan mahasiswa Program Studi Pendidikan Seni Pertunjukan, Fakultas Seni Pertunjukan ISI Yogyakarta. Pelaksanaan perlakuan (treatment) dilakukan di ruang terbuka (plaza) Fakultas Seni Pertunjukan ISI Yogyakarta. Dipilihnya ruang terbuka dalam pelaksanaan perlakuan (treatment) agar para subjek lebih leluasa dalam bergerak dan pemutaran bilah. Selain itu, apabila tali bilah terputus maka tidak terkena sesuatu. Perlakuan (treatment) dilaksanakan dalam tiga tahap. Tahap pertama merupakan tahap adaptasi dengan media (bilah), tahap kedua melakukan gerak secara improvisasi bebas, dan tahap ketiga melakukan gerak secara improvisasi terkendali. Pelaksanaan perlakuan (treatment) diatur masing-masing subjek penelitian hadir dalam waktu yang berbeda. Hal tersebut di- lakukan agar tidak terjadi bias di antara para subjek dalam melakukan perlakuan (treatment) karena terpengaruh subjek lain.

Subjek yang dikenai perlakuan (treatment) dalam penelitian ini keseluruhannya pernah mengalami accident (cedera) dalam suatu pertunjukan tari. Subjek 1 pernah terpeleset dan jatuh, disebabkan pada saat turun dari punggung penari lain dalam kondisi tidak siap. Hal tersebut disebabkan oleh kecepatan waktu dalam menyelesaikan suatu gerakan yang dibingkai oleh suasana iringan. Artinya, pada saat turun dari punggung salah satu penari dan harus melakukan gerak lain, tidak cukup waktu untuk mengejar ketertinggalan dalam bergerak. Dengan demikian, ketergesagesaan tanpa disertai kesadaran dalam mengordinasikan instrumen tubuh dengan gerak yang akan dilakukan tidak sejalan. Namun demikian, subjek 1 tidak merasa kesakitan dan tetap melanjutkan menari. Berbeda dengan subjek 2 pernah terluka kakinya disebabkan terkena sesuatu pada saat menari. Walaupun kaki terluka tetap melanjutkan menari. Sementara subjek 3 mengalami cedera yang menyebabkan tulang pada telapak kaki patah. Kejadian yang dialami dalam Festival Sendratari DIY pada tahun 2018 tersebut disebabkan ketidakseimbangan pada waktu meloncat dari punggung penari. Walaupun tulang telapak kaki patah pada saat menari, tidak terasa sakit dan tetap melanjutkan menari selama kurang lebih tujuh menit. Demikian pula pada subjek 4 dan subjek 5 pernah mengalami cedera kaki pada saat latihan untuk mempersiapkan suatu pertunjukan tari. Walaupun tidak merasakan sakit pada saat menari dan baru terasa setelahnya, akan lebih baik apabila tidak terjadi accident dalam suatu pentas. Peristiwa yang dialami para subjek tersebut menjadi pelajaran tentang perlunya pengendalian diri pada saat bergerak atau menari.

\section{Perlakuan (Treatment) Pertama}

Pada pelaksanaan perlakuan (treatment) pertama pada umumnya para subjek masih 
beradaptasi dengan bilah. Proses adaptasi diperlukan karena para subjek baru pertama kali mengenal bilah sebagai media dalam latihan olah tubuh. Rencana awal perlakuan (treatment) dilakukan dalam durasi empat menit. Namun demikian, pada saat subjek 1 melakukan adaptasi bilah dengan melakukan latihan olah tubuh selama empat menit, terlihat kelehahan. Kelelahan yang menyebabkan intensitas pemutaran kurang optimal. Dengan demikian, apabila dilakukan dalam durasi empat menit atau lebih perlakuan penggunaan bilah untuk latihan olah tubuh akan menimbulkan bias. Atas dasar itu, pelaksanaan perlakuan (treatment) durasi dipersingkat menjadi dua menit bagi setiap subjek berikutnya.

Pada pelaksanaan perlakuan pertama para subjek masih merasa khawatir dengan perputaran bilah, belum dapat mengontrol arah putaran bilah, dan masih fokus pada bilah. Oleh karena itu, para subjek dalam memutarkan bilah yang disertai dengan latihan olah tubuh cenderung lambat dan fokus pada bilah. Akibatnya, proses bergerak cenderung mencari aman agar bilah tidak mengenai badan. Dengan demikian, proses adaptasi pemutaran bilah sambil bergerak atau latihan olah tubuh menjadi lebih lambat. Namun, selama 2 menit melakukan latihan olah tubuh sambil memutarkan bilah, terjadi kasus bilah mengenai badan, bilah mengenai lantai, dan tali bilah mengendor terinci dapat dilihat pada tabel 1 .

Pada tabel 1 tersebut bilah mengenai badan secara akumulatif terdapat 7 kasus, bilah terkena lantai nol kasus, dan tali mengendor 5 kasus. Hal tersebut menunjukkan bahwa bilah

Tabel 1. Jumlah bilah diluar kendali.

\begin{tabular}{lcccc}
\hline Pelaku & $\begin{array}{c}\text { Bilah } \\
\text { Treatment } \\
\text { Badan } \\
\text { Badain }\end{array}$ & $\begin{array}{c}\text { Bilah } \\
\text { Mengenai } \\
\text { Lantai }\end{array}$ & $\begin{array}{c}\text { Tali } \\
\text { Mengendor }\end{array}$ & Jumlah \\
\hline 1. Subjek 1 & 2 & - & 1 & 3 \\
2. Subjek 2 & 2 & - & 1 & 3 \\
3. Subjek 3 & - & - & 2 & 2 \\
4. Subjek 4 & 1 & - & - & 1 \\
5. Subjek 5 & 2 & - & 1 & 3 \\
\hline
\end{tabular}

di luar kendali secara akumulatif berjumlah 12 kasus.

\section{Perlakuan (Treatment) Kedua}

Perlakuan (treatment) kedua membebaskan setiap subjek untuk bergerak secara bebas menurut cara masing-masing. Setiap subjek melakukan improvisasi gerak atau latihan olah tubuh tanpa dibatasi oleh suatu perlakuan tertentu. Proses latihan olah tubuh dilakukan sambil memutarkan bilah. Berdasarkna pada perlakuan pertama para subjek telah melakukan adaptasi bilah, maka pada perlakuan kedua para subjek dalam melakukan latihan olah tubuh sambil memutarkan bilah lebih percaya diri, bebas, dan lebih konsentrasi. Bagi seorang penari, konsentrasi merupakan kesanggupan penari untuk mengarahkan seluruh kekuatan rohani dan pikiran ke arah suatu sasaran yang jelas dan melanjutkannya terus-menerus selama dikehendaki.

Pada pelaksanaan perlakukan (treatment) ke dua, proses pengamatan (observasi) diperlukan kecermatan. Proses pengamatan terhadap kasus yang terjadi selama latihan olah tubuh yang disertai pemutaran bilah agar dapat tercatat dengan saksama. Hasil catatan sebagai dasar untuk menganalisis terhadap latihan olah tubuh sambil memutarkan bilah yang dilakukan para subjek, dan terjadinya kasus bilah di luar kendali. Kasus di luar kendali dimaksudkan bahwa bilah mengenai badan, mengenai lantai, dan tali kendor merupakan

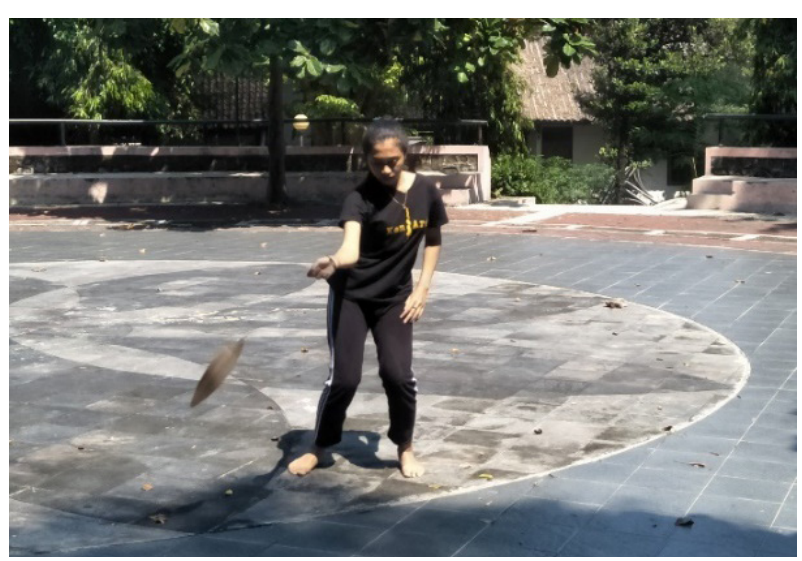

Gambar 1. Proses adaptasi bilah. (Foto: Sarjiwo, 2021) 
accident di luar kendali. Pembebasan para subjek untuk melakukan eksplorasi bilah sambil melakukan improvisasi gerak mampu memunculkan berbagai ragam gerak lebih variatif. Berbagai desain gerak ataupun ruang terlihat dinamis. Walaupun dilakukan selama dua menit dalam melakukan perlakuan, para subjek menunjukkan kesungguhan dalam mengeksplorasi bilah ataupun dalam melakukan improvisasi gerak. Hal tersebut terlihat dari keringat yang membasahi tubuh para subjek.

Adanya kebebasan para subjek melakukan eksplorasi bilah dan improvisasi gerak, memotivasi subjek untuk memutarkan bilah dengan semangat. Hal tersebut dapat diketahui dari bilah yang bersuara keras. Dengungan suara bilah menandakan adanya putaran bilah yang berputar cepat akibat dari tenaga subjek

Tabel 2. Jumlah bilah diluar kendali.

\begin{tabular}{lcccc}
\hline $\begin{array}{c}\text { Pelaku } \\
\text { Treatment }\end{array}$ & $\begin{array}{c}\text { Bilah } \\
\text { Mengenai } \\
\text { Badan }\end{array}$ & $\begin{array}{c}\text { Bilah } \\
\text { Mengenai } \\
\text { Lantai }\end{array}$ & $\begin{array}{c}\text { Tali } \\
\text { Mengendor }\end{array}$ & Jumlah \\
\hline 1. Subjek 1 & 2 & 2 & - & 4 \\
2. Subjek 2 & 1 & 1 & 4 & 6 \\
3. Subjek 3 & 1 & 4 & - & 5 \\
4. Subjek 4 & 1 & - & 2 & 3 \\
5. Subjek 5 & 1 & - & 2 & 3 \\
\hline
\end{tabular}

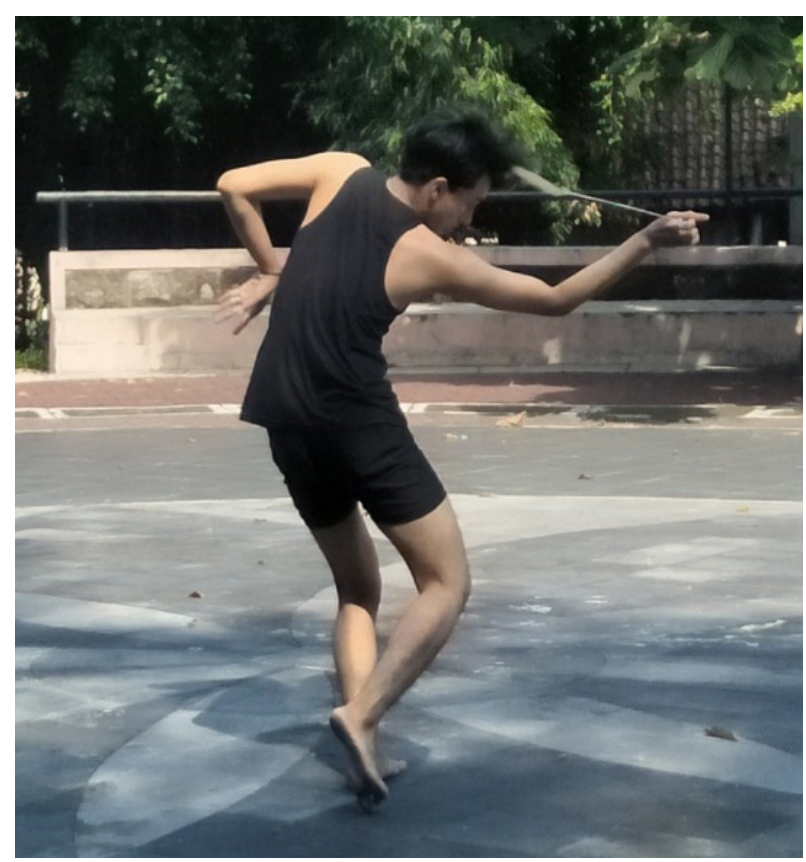

Gambar 2. Proses improvisasi gerak bebas sambil memutarkan bilah. (Foto: Sarjiwo, 2021) yang kuat. Keras-lemahnya suara dengungan bilah mengindikasikan bahwa subjek melakukan perlakuan (treatment) secara intens. Dengan demikian, gerak tubuh dan arah perputaran bilah perlu dikoordinasikan dengan baik. Pada perlakuan (treatment) ke dua ini terjadi kasus (accident) bilah mengenai badan, mengenai lantai, tali mengendor dapat dilihat pada tabel 2 .

Pada tabel 2 tersebut bilah mengenai badan secara akumulatif terdapat 6 kasus, bilah terkena lantai 7 kasus, dan tali mengendor 8 kasus. Secara akumulatif hal tersebut menunjukkan bahwa bilah di luar kendali berjumlah 21 kasus.

\section{Perlakuan (Treatment) Ketiga}

Perlakuan (treatment) ketiga merupakan treatment terkendali. Perlakuan (treatment) terkendali dimaksudkan bahwa di dalam latihan olah tubuh sambil memutarkan bilah para subjek dibingkai oleh kesadaran untuk mengendalikan diri dalam bergerak. Pengendalian diri diperlukan untuk melatih dan membiasakan terhadap pengendalian emosi yang diperlukan dalam menari. Kemampuan mengendalikan emosi dapat mengantarkan menjadi orang yang lebih baik, dan akan mudah dalam memilah yang baik dan hal yang sebaiknya dihindari (Adam, 2020). Pernyataan tersebut dapat diadopsi pengertiaannya bahwa seorang penari diharapkan mampu mengendalikan diri dan mampu menghindari sesuatu yang dapat mencederai diri. Dengan demikian, bergerak yang berlebihan (over acting) sebaiknya dihindari agar tidak terjadi sesuatu yang tidak diharapkan.

Pada perlakuan (treatment) ke tiga para subjek lebih menikmati putaran bilah sehingga proses bergerak lebih tenang. Bahkan subjek merasakan bahwa bilah sudah menjadi bagian dari tubuh. Pada perlakuan (treatment) ke tiga terjadi kesadaran dalam mengatur intensitas energi dan membantu kesadaran pengaturan emosi. Pemutaran bilah yang disertai proses 
bergerak mampu melatih kepekaan intensitas energi dan dapat melatih keseimbangan tubuh. Intensitas energi dan keseimbangan sangat penting bagi seorang penari. Beberapa kasus, seperti penari terjatuh, terpeleset, dan cedera yang lain, disebabkan kurang adanya keseimbangan tubuh. Sementara intensitas energi sangat diperlukan dalam menari disebabkan pada saat menari tidak lepas dari pengaturan energi, sebagaimana konsep ebahing saranduning badan (bergeraknya seluruh bagian tubuh).

Pelaksanaan perlakuan (treatment) ke tiga proses bergerak yang dibingkai oleh perilaku gerak yang terkait dengan

Tabel 3. Jumlah bilah diluar kendali.

\begin{tabular}{lcccc}
\hline No. $\begin{array}{c}\text { Pelaku } \\
\text { Treatment }\end{array}$ & $\begin{array}{c}\text { Bilah } \\
\text { Mengenai } \\
\text { Badan }\end{array}$ & $\begin{array}{c}\text { Bilah } \\
\text { Mengenai } \\
\text { Lantai }\end{array}$ & $\begin{array}{c}\text { Tali } \\
\text { Mengendor }\end{array}$ & Jumlah \\
\hline 1. Subjek 1 & 1 & - & - & 1 \\
2. Subjek 2 & - & 1 & 1 & 2 \\
3. Subjek 3 & 1 & - & 1 & 2 \\
4. Subjek 4 & - & - & 1 & 1 \\
5. Subjek 5 & 1 & - & - & 1 \\
\hline \multicolumn{5}{l}{} \\
& & & Jumlah Total $=$ & 7
\end{tabular}

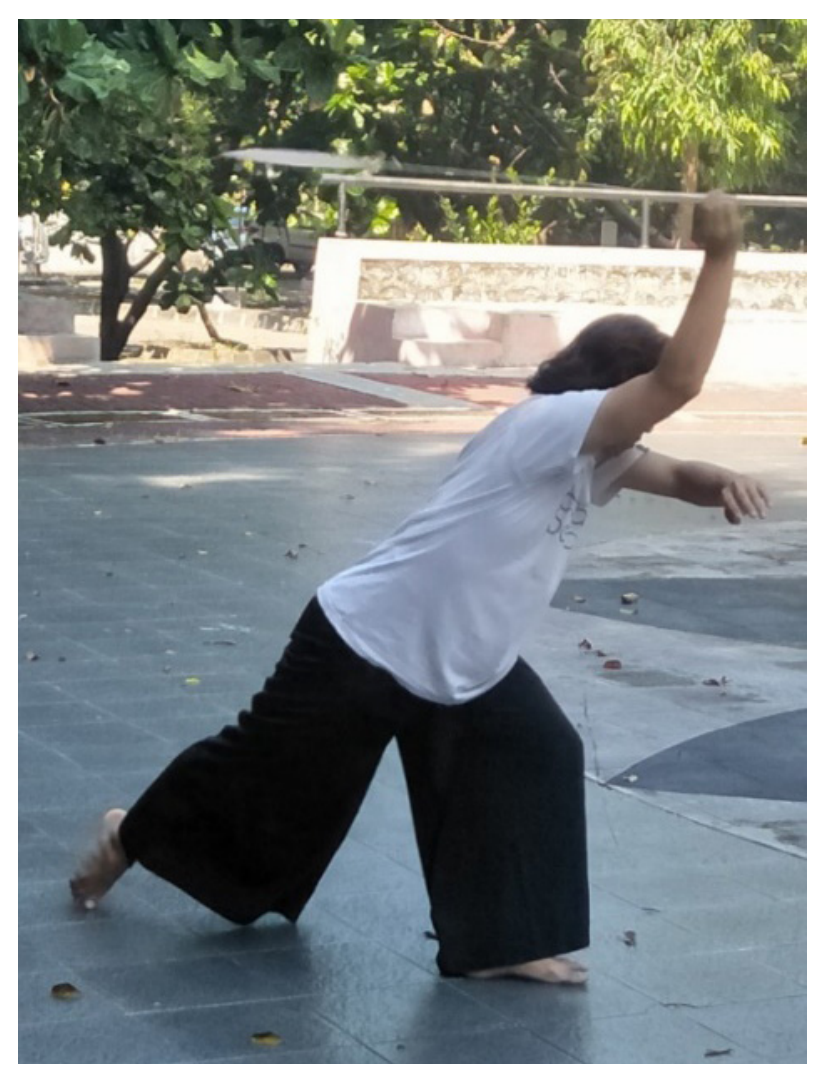

Gambar 3. Proses improvisasi terkendali. (Foto: Sarjiwo, 2021) pengendalian diri dapat dilakukan para subjek dengan baik. Adanya pernyataan bahwa bilah telah menjadi bagian dari tubuh, menandakan bahwa proses bergerak tidak terganggu oleh bilah. Telah terjadinya relasi antara subjek dan objek (bilah), keduanya bersifat fungsional yang saling membutuhkan. Subjek terbuka bagi objek dan sebaliknya (Peursen, 1988). Kordinasi antara bilah dan proses improvisasi gerak, dapat dilakukan secara insting tanpa ada hambatan. Pada perlakuan ke tiga, para subjek mampu menunjukkan proses bergerak lebih tenang yang menandakan adanya pengaturan energi yang terkendali. Hal tersebut dapat diketahui dari bilah yang mengenai badan secara akumulatif sebanyak 7 kali, mengenai lantai 1 kali, dan tali mengendor secara akumulatif sebanyak 3 kali. Secara rinci dapat dilihat pada tabel 3 .

\section{Penutup}

Bilah sebagai media pembelajaran olah tubuh merupakan hasil perancangan yang diharapkan dapat menambah ilmu tari, khususnya dalam latihan olah tubuh yang terkait dengan pengendalian diri. Pengendalian diri pada saat menari, diperlukan agar dalam bergerak selaras dengan kapasitas tubuhnya. Penglebih-lebihan gerak yang tidak sesuai dengan kapasitas tubuh dan koridor koreografi, akan memunculkan perilaku over acting. Over acting yang dapat menimbulkan sesuatu yang tidak dikehendaki. Sebab, di dalam tari, seorang penari diharapkan mampu menjadikan tubuh sebagai instrumen untuk kepentingan ekspresi tari. Oleh karena itu, perancangan media pembelajaran olah tubuh untuk melatih gerak dalam pengendalian diri dimaksudkan agar dapat dimanfaatkan dalam proses pembiasaan saat berlatih.

Hasil perancangan bilah tidak akan diketahui manfaatnya tanpa adanya ujicoba (eksperimen) penggunaan bilah. Ujicoba (eksperimen) dilakukan dalam suatu perlakuan (treatment) yang dilakukan para subjek dalam tiga tahap, yaitu pertama tahap adaptasi 
dengan media (bilah), tahap kedua melakukan gerak secara improvisasi bebas, dan tahap ketiga melakukan gerak secara improvisasi terkendali. Dari hasil ujicoba bilah dalam tiga kali perlakuan dapat disimpulkan bahwa:

1. Pada perlakukan pertama bilah yang diputar para subjek mengenai badan, mengenai lantai, dan tali kendor secara akumulatif berjumlah 12 (dua belas) kali.

2. Pada perlakukan kedua, bilah yang diputar para subjek mengenai badan, mengenai lantai, dan tali kendor secara akumulatif berjumlah 21 (dua puluh sat) kali.

3. Pada perlakukan ketiga, bilah yang diputar para subjek mengenai badan, mengenai lantai, dan tali kendor secara akumulatif berjumlah 7 (tujuh) kali. Hasil tersebut menunjukkan bahwa apabila dalam bergerak bebas tidak terkendali kemungkinan terjadi kasus (accident) lebih besar (21 kali). Sedangkan apabila dalam bergerak terkendali maka kemungkinan terjadi $a c$ cident lebih kecil (7 kali). Berdasarkan hasil dari perlakuan tersebut dapat disimpulkan bahwa bilah dapat dipakai sebagai media pembelajaran olah tubuh untuk melatih gerak dalam pengendalian diri.

\section{Ucapan Terima Kasih}

Ucapan terima kasih ditujukan kepada Bapak Sujiman, pengrajin kayu dan topeng dari Desa Bobung, Putat, Gunungkidul yang telah bersedia dalam pembuatan bilah. Para mahasiswa dari Program Studi Tari dan Program Studi Pendidikan Seni Pertunjukan Fakultas Seni Pertunjukan ISI Yogyakarta yang telah bersedia menjadi subjek dalam uji coba (eksperimen) perancangan bilah. Lembaga Penelitian dan Pengabdian ISI Yogyakarta yang telah mendanai perancangan pembuatan bilah beserta uji coba (eksperimen) penggunaan bilah.

\section{KEMENTERIAN HUKUM DAN HAK ASASI MANUSIA REPUBLIK INDONESIA}

\section{SURAT PENCATATAN CIPTAAN}

\section{Pencipta}

Nama : Dr. Sarjiwo, M.Pd.

Kewarganegaraan : Indonesia

Jenis Ciptaan : Alat Peraga

Judul Ciptaan : Bilah Berputar

\section{Pemegang Hak Cipta}

Nama : LPPM Institut Seni Indonesia Yogyakarta Alamat : Gd. Concert Hall Lt.3 Kompleks Kampus ISI Yogyakarta Jl. Parangtritis Km. 6,5, Bantul, DI Yogyakarta, 55188

Tanggal dan tempat diumumkan untuk pertama kali di wilayah Indonesia atau di luar wilayah Indonesia : 6 Oktober 2021, di Yogyakarta

Jangka waktu pelindungan : Berlaku selama 50 (lima puluh) tahun sejak Ciptaan tersebut pertama kali dilakukan

\section{Pengumuman}

Nomor pencatatan : 000308424

adalah benar berdasarkan keterangan yang diberikan oleh Pemohon.

Surat Pencatatan Hak Cipta atau produk Hak terkait ini sesuai dengan Pasal 72 Undang-Undang Nomor 28 Tahun 2014 tentang Hak Cipta.

\section{Kepustakaan}

Adam, B. 2020. Seni Mengenal Diri Sendiri. Yogyakarta: Bright Publisher.

Armstrong, T. 2009. Multiple Intelligences in the Classroom in Education (3rd Editio). Alexandria, Virginia USA: ASCD Member Book.

Sabrina, C. 2020. Seni Mengendalikan Emosi. Yogyakarta: Bright Publisher.

Setiyastuti, B. 2011. Melatih Tubuh: Sebuah Metode Baru Olah Tubuh Dalam Tari. Harmonia: Journal of Arts Research and Education, 11(1), 15-25. https://doi. org/10.15294/harmonia.v11i1.2069

van Peursen, C. A. 1988. Srategi Kebudayaan. Yogyakarta: Kanisius.

Widaryanto, F. X. (2019). Menyoal Ketubuhan dan Nilai Performatifnya. Dance and Theatre Review, 2(2), 53-63. https://doi. org/10.24821/dtr.v2i2.3309

Zuchdi, D. (Editor). (2011). Pendidikan Karakter dalam Perspektif Teori dan Praktek. Yogyakarta: UNY Press. 